\title{
Commentary
}

\section{DNA hybridization arrays: a powerful technology for nutritional and obesity research}

Obesity is a serious and growing public health problem throughout much of the world. In fact, obesity has reached epidemic proportions in many developed countries. Increased food intake and decreased energy expenditure due to the sedentary lifestyle of our developed societies have contributed to the widespread development of obesity. However, these environmental factors cannot totally explain the development of the disorder. In fact, genetic predisposition for obesity may underlie the increased tendency for weight gain in some individuals (Levin, 2000; Marti et al. 2000). Recent research has identified over 200 genes, markers and chromosomal regions associated with or linked to human obesity (Chagnon et al. 2000). The contribution of genetic background to obese phenotypes is a complex question yet to be answered. The major aim, therefore, is to study those combinations of genes and mutations that are implicated in the development of obesity in human subjects. In order to be able to control the spread of obesity, it is necessary to establish how environmental factors affect the onset of obesity in individuals with a specific genetic background.

With potentially thousands of genes examined in a single hybridization, DNA hybridization array technology constitutes a powerful tool to identify and compare patterns of gene expression (Lander, 1999; Yang et al. 1999). Thousands of DNA spots are robotically deposited on a solid-state matrix (nylon membranes, glass microscope slides, silicon or ceramic chips). These matrixes are then hybridized with labelled cDNA representing total RNA pools from test and reference samples. The differential expression of genes between both test and reference samples are detected based on the fact that the higher the expression of a gene, the higher the intensity of the output labelled signal (Schena et al. 1995, 1996; Duggan et al. 1999).

An array starts with the selection of the 'probes' to be printed in the array. In many cases these probes are chosen directly from databases like Genbank (Benson et al. 1998), dbEST (Boguski et al. 1993) and UniGene (Schuler et al. 1996), the resource backbones of the array technologies (Duggan et al. 1999). There are a variety of options for making arrays (Bowtell, 1999; Cheung et al. 1999), with four different array types developed according to the different characteristics of the matrix, probe number and density, array size and type of label. These include macroarrays, microarrays, high-density oligonucleotide arrays and microelectronic arrays (Freeman et al. 2000). In the macroarrays the DNA probes are immobilized on a membrane-based matrix, the targets are radioactively labelled, and the different samples are hybridized on individual separate arrays. Phosphoimagers are then used to detect the amount of bound labelled target. Microarrays are produced by spotting up to 10000 polymerase chain reaction products, or more, representing specific genes, onto a glass or plastic slide matrix (Schena et al. 1995). Following purification and quality control, a few nanolitres of the polymerase chain reaction product are printed on coated glass microscope slides using a computer-controlled high-speed robot. Total RNA from both the test and reference samples is labelled with fluorescent tags (for example, red and green dye) by a single round of reverse transcription. The matrix is then simultaneously hybridized with the two resulting fluorescently-labelled cDNA in a competitive manner, and fluorescence scanners are used for detection (Schena et al. 1995, 1996; Fig. 1). The highdensity oligonucleotide arrays differ from the microarrays in that the DNA probe is generated in situ on the surface of the matrix by a method called photolitography. These arrays (Genechips ${ }^{\circledR}$; Affymetrix, Santa Clara, CA, USA) can contain between 40000 and 60000 probes, providing the highest density of probes of any array. However, the probes are limited in length and therefore specificity, and a mismatch detection scheme has to be used to determine specific hybridization (Lipshutz et al. 1999; Freeman et al. 2000). The microelectronic arrays, the newest hybridization array, consist of sets of electrodes covered by a thin layer of agarose coupled with an affinity moiety which provides controlled electrophoretic fields (Cheng et al. 1998; Heller et al. 2000).

Analysis and handling of the array data is one of the most difficult aspects in the utilization of the technology. The images of the scanner are imported into software which has to transform the fluorescence data into information about the clones, such as gene name, clone identifier, intensity values, intensity ratios, normalization constant and CI (Duggan et al. 1999). Clustering algorithms (hierarchical and nonhierarchical) have been the most used tools for analysing array data, and make it possible to find groups of genes or clusters with similar behaviour (Brazma \& Vilo, 2000; Celis et al. 2000).

Due to the adaptable nature of the fabrication and hybridization methods, these techniques have been widely applied. Hybridization arrays have been applied to the discovery of sets of genes that have roles in diseases such as cancer (DeRisi et al. 1996; Kononen et al. 1998; Cole et al. 1999; Marx, 2000; Sallinen et al. 2000), insulin resistance (Aitman et al. 1999), hypertension (Lee et al. 2000), rheumatoid arthritis and inflammatory bowel disease (Heller et al. 1997). 


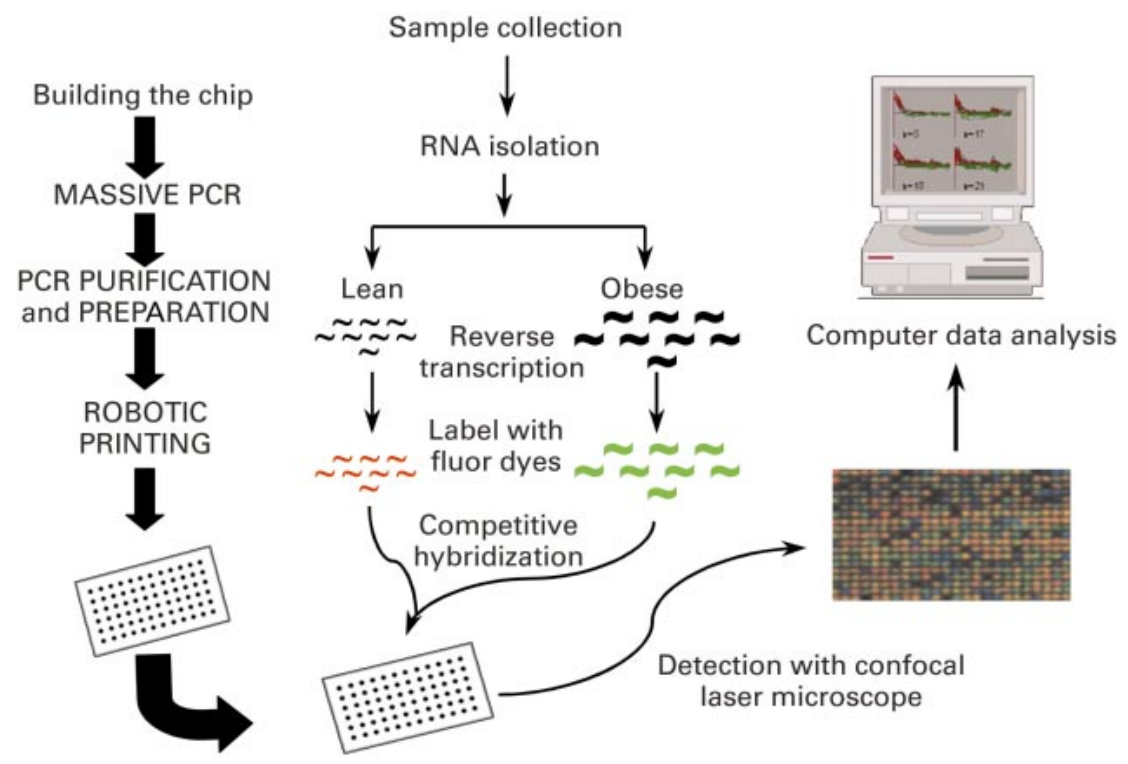

Fig. 1. cDNA microarray schema: polymerase chain reaction $(P C R)$ products representing specific genes are robotically printed on a glass or plastic matrix. RNA samples from lean and obese individuals are fluorescently labelled by a single round of reverse transcription, and then competitively hybridized to the same array. Fluorescent scanners are used for detection and the microarray data are analysed with sophisticated computer programs.

cDNA biochips, therefore, constitute an extraordinary tool for use by nutritionists (Trayhurn, 1998) and obesity researchers to identify those combinations of genes (known and unknown) that are implicated in the development of obesity and other nutrition-related disorders. A recent study has reported on the use of DNA microarray technology to assess the changes in gene expression associated with obesity and diabetes in lean, obese and diabetic mice. The expression level of $>11000$ transcripts was analysed, finding that the expression of adipogenic genes was reduced in obesity and diabetes (Nadler et al. 2000). Oligonucleotide microarrays have also been used to study the components of the transcriptional programme specifically affected by leptin in $o b / o b$ mice. This study found that many adipose tissue genes were differentially expressed between $o b / o b$ and lean mice, and also identified a series of gene clusters that are specifically regulated by leptin and that distinguish leptin treatment from food restriction (Soukas et al. 2000). Microarray technology, therefore, is providing insight into the molecular events implicated in the development of obesity, diabetes and other nutritionally-related disorders that would be difficult to obtain using the traditional geneby-gene approach.

Oligonucleotide microarray (DNA chip)-based hybridization analysis also constitutes a promising new technology for exploring the genome (Brown \& Botstein, 1999). Thus, Gabrielsson et al. (2000) have performed a partial genome scale analysis of gene expression in human adipose tissue using DNA array. This study allowed the identification of numerous genes not previously reported to be expressed in adipose tissue, suggesting novel candidate genes involved in the pathophysiology of obesity (Gabrielsson et al. 2000).

Array technology can also be used for the screening of possible mutations and sequence variations in genomic
DNA (Hacia, 1999). Microarray technology, therefore, constitutes a useful tool in clinical diagnosis by detecting gene expression mutations associated with disease states in either biopsies or peripheral blood cells (Brugarolas et al. 2001). In this sense, a Gene Chip p53 assay has been used to detect the accumulation of p53 mutations during carcinogenesis and the development of gastrointestinal cancers (Takahashi et al. 2000). With regard to obesity, spontaneous mutations in five different genes have been found to be responsible for obesity in mouse models of obesity, i.e. the obese $(o b)$, diabetes $(d b)$, the agouti yellow $\left(A^{y}\right)$, the fat and tubby mutations. Mutations in some of these genes have also been related to the susceptibility to develop obesity in man (for review, see Bouchard et al. 1999). In addition, studies published in the last few years have provided evidence for an association between obesity-related phenotypes and polymorphisms in uncoupling proteins 2 and 3 , peroxisome proliferator-activated receptor $\gamma, \beta_{2}$ -adrenergic receptor, apolipoprotein A4, insulin receptor substrate I (for review, see Chagnon et al. 2000). Furthermore, several groups reported additive effects of polymorphisms on the development of obesity. One example is the finding that the polymorphism in the uncoupling protein 1 and $\beta_{3}$-adrenergic receptor genes had an additive action on weight loss (Fogelholm et al. 1998; Kogure et al. 1998).

DNA hybridization arrays, therefore, represent a huge opportunity to study the association of a number of different polymorphisms with the development of obesity. In addition, the design of cDNA chips that allow the identification of possible mutations in candidate genes related to obesity might soon be very useful in clinical practice. The cDNA chips will help to characterize the aetiology of obesity and, therefore, a better approach for its 
treatment. In addition, the early identification of the genetic predisposition to obesity will enable physicians to choose the appropriate preventive intervention for each patient, involving nutritional or exercise programmes. In this sense it has been shown that the association of some gene polymorphisms with an obese phenotype depends on the environment (diet and physical activity). For example, the Gln27Glu polymorphism of the $\beta_{2}$-adrenergic receptor gene is associated with high body weight and BMI in sedentary men but not in physically active men (Meirhaeghe et al. 1999).

DNA chips will also be very useful to study the effects of the type of nutrients in the diet on the expression of obesityrelated genes. A recent study has already used DNA expression arrays to determine the effect of energy restriction on the age-related changes in gene expression (Han et al. 2000). It has been proposed that DNA chips will soon be used to monitor gene expression in response to a wide variety of nutritional events (Roberts et al. 2000).

DNA microarray technology is also being used in drug discovery and development. The opportunity to compare the expression of thousands of genes between 'disease' and 'normal' tissues and cells will allow the identification of multiple potential targets for therapeutic intervention (Debouck \& Goodfellow, 1999). Two recent studies have used microarrays as a tool for investigating the mechanism of drug action (Gray et al. 1998; Marton et al. 1998). Differential gene expression technologies have also been used for elucidating both drug efficacy and toxicity, as well as novel candidate genes for pharmacogenetic analyses to assess individual variability to drug response (Nuwaysir et al. 1999; Rininger et al. 2000). $\beta_{3}$-Adrenergic agonists have been described as potential anti-diabetic and antiobesity drugs, through effects on white adipose tissue. cDNA microarrays have been used to explore the molecular mechanisms of this response to $\beta_{3}$-adrenergic agonists. These studies found that the drugs alter the expression of some adipose tissue genes such as fibroblast growth factor and tumour necrosis factor $\alpha$-induced protein, which may modulate the $\beta_{3}$-adrenergic inhibition of food intake (Ye et al. 2000). The cDNA chips, therefore, can be useful tools for the discovery of anti-obesity drugs, as well as for the identification of their mechanisms of action.

In summary, cDNA array technology, despite some limitations such as the high cost, provides a powerful opportunity for obesity researchers and nutritionists. This technology constitutes the appropriate tool for studying those combinations of genes and mutations that are involved in the development of obesity in man, as well as for establishing the participation of environmental factors on the onset of obesity in individuals with a specific genetic background.

$$
\begin{array}{r}
\text { M. J. Moreno-Aliaga }{ }^{1} \text {, A. Marti }{ }^{1} \text {, J. García-Foncillas }{ }^{2} \\
\text { and J. Alfredo Martínez }{ }^{1} \\
{ }^{1} \text { Department of Physiology and Nutrition and } \\
{ }^{2} \text { Cellular Therapy Unit } \\
\text { University of Navarra } \\
31080 \text { Pamplona } \\
\text { Spain }
\end{array}
$$

\section{References}

Aitman TJ, Glazier AM, Wallace CA, Cooper LD, Norsworthy PJ, Wahid FN, Al-Majali KM, Trembling PM, Mann CJ, Shoulders CC, Graf D, St Lezin E, Kurtz TW, Kren V, Pravenec M, Ibrahimi A, Abumrad NA, Stanton LW \& Scott J (1999) Identification of Cd36 (Fat) as an insulin-resistance gene causing defective fatty acid and glucose metabolism in hypertensive rats. Nature Genetics 21, 76-83.

Benson DA, Bogusky MS, Lipman DJ, Ostell J \& Ouellette BF (1998) GenBank. Nucleic Acids Research 26, 1-7.

Boguski MS, Lowe TM \& Tolstoshev CM (1993) DbESTdatabase for 'expressed sequence tags'. Nature Genetics 4, $332-333$.

Bouchard C, Pérusse L \& Chagnon YC (1999) Genes and human obesity. In Nutrition, Genetics, and Obesity, vol. 9, pp. 25-46 Pennington Center Nutrition Series, [GA Bray and DH Ryan, editors]. New Baton Rouge, LA: Louisiana State University Press.

Bowtell D (1999) Options available - from start to finish - for obtaining expression data by microarray. Nature Genetics $\mathbf{2 1}$, $25-32$.

Brazma A \& Vilo J (2000) Gene expression data analysis. FEBS Letters 480, 17-24.

Brown PO \& Botstein D (1999) Exploring the new world of the genome with DNA microarrays. Nature Genetics 21, 33-37.

Brugarolas J, Haymes BH \& Nevins JR (2001) Towards a genomic-based diagnosis. Lancet 357, 249-250.

Celis JE, Kruhoffer M, Gromova I, Frederiksen C, Ostergaard M, Thykjaer T, Gromov P, Yu J, Palsdottir H, Magnusson N \& Orntoft TF (2000) Gene expression profiling: monitoring transcription and translation products using DNA microarrays and proteomics. FEBS Letters 480, 2-16.

Chagnon YC, Pérusse L, Weisnagel SJ, Rankinen T \& Bouchard C (2000) The human obesity gene map: the 1999 update. Obesity Research 8, 89-117.

Cheng J, Sheldon EL, Wu L, Uribe A, Gerrue LO, Carrino J, Heller MJ \& O'Connell JP (1998) Preparation and hybridization analysis of DNA/RNA from $E$. coli on microfabricated bioelectronic chips. Nature Biotechnology 16, 541-546.

Cheung VG, Morley M, Aguilar F, Massimi A, Marcherlapati R \& Childs G (1999) Making and reading microarrays. Nature Genetics 21, 15-19.

Cole KA, Krizman DB \& Emmert-Buck MR (1999) The genetics of cancer - a 3D model. Nature Genetics 21, 38-41.

DeRisi JL, Penland JL, Brown PO, Bittner ML, Meltzer PS, Ray M, Chen Y, Su YA \& Trent JM (1996) Use of a cDNA microarray to analyse gene expression patterns in human cancer. Nature Genetics 14, 457-460.

Debouck C \& Goodfellow PN (1999) DNA microarrays in drug discovery and development. Nature Genetics 21, 48-50.

Duggan DJ, Bittner M, Chen Y, Meltzer P \& Trent M (1999) Expression profiling using cDNA microarrays. Nature Genetics 21, 10-14.

Fogelholm M, Valve R, Kukkonen-Harjula K, Nenonen A, Hakkarainen V, Laakso M \& Uusitupa M (1998) Additive effects of the mutations in the beta (3)-adrenergic receptor and uncoupling protein-1 genes on weight loss and weight maintenance in Finnish women. Journal of Clinical Endocrinology and Metabolism 83, 4246-4250.

Freeman WM, Robertson DJ \& Vrana KE (2000) Fundamentals of DNA hybridization arrays for gene expression analysis. Biotechniques 29, 1042-1055.

Gabrielsson BL, Carlsson B \& Carlsson LMS (2000) Partial genome scale analysis of gene expression in human adipose tissue using DNA array. Obesity Research 8, 374-384. 
Gray NS, Wodicka L, Thunnissen AM, Norman TC, Kwon S, Espinoza FH, Morgan DO, Barnes G, LeClerc S, Meijer L, Kim SH, Lockhart DJ \& Schultz PG (1998) Exploiting chemical libraries, structure, and genomics in the search for kinase inhibitors. Science 281, 533-538.

Hacia JG (1999) Resequencing and mutational analysis using oligonucleotide microarrays. Nature Genetics 21, 42-47.

Han E, Hilsenbeck SG, Richardson A \& Nelson JF (2000) cDNA expression arrays reveal incomplete reversal of age-related changes in gene expression by calorie restriction. Mechanism of Ageing and Development 115, 157-174.

Heller MJ, Forster AH \& Tu E (2000) Active microelectronic chip devices which utilize controlled electrophoretic fields for multiplex DNA hybridization and other genomic applications. Electrophoresis 21, 157-164.

Heller RA, Schena M, Chai A, Shalon D, Bedilion T, Gilmore J, Woolley DE \& Davis RW (1997) Discovery and analysis of inflammatory disease-related genes using cDNA microarrays. Proceedings of the National Academy of Sciences USA 94, 2150-2155.

Kogure A, Yoshida T, Sakane N, Umekawa T, Takakura Y \& Kondo M (1998) Synergic effect of polymorphisms in uncoupling protein 1 and beta3-adrenergic receptor genes on weight loss in obese Japanese. Diabetologia 41, 1399.

Kononen J, Bubendorf L, Kallioniemi A, Barlund M, Schraml P, Leighton S, Torhorst J, Mihatsch MJ, Sauter G \& Kallioniemi OP (1998) Tissue microarrays for high-throughput molecular profiling of tumour specimens. Nature Medicine 4, 844-847.

Lander ES (1999) Array of hope. Nature Genetics 21, 3-4.

Lee WK, Padmanabha S \& Dominiczak AF (2000) Genetics of hypertension: from experimental models to clinical applications. Journal of Human Hypertension 14, 631-647.

Levin BE (2000) The obesity epidemic: metabolic imprinting on genetically susceptible neural circuits. Obesity Research 8, 342-347.

Lipshutz RJ, Fodor SP, Gingeras TR \& Lockhart D (1999) High density synthetic oligonucleotide arrays. Nature Genetics 21, 20-24.

Marti A, Miguel C, Jebb SA, Lafontan M, Laville M, Palou A, Remesar X, Trayhurn P \& Martinez JA (2000) Methodological approaches to assess body-weight regulation and aetiology of obesity. Proceedings of the Nutrition Society 59, 405-411.

Marton MJ, DeRisi JL, Bennett HA, Iyer VR, Meyer MR, Roberts CJ, Stoughton R, Burchard J, Slade D, Dai H, Bassett DE Jr, Hartwell LH, Brown PO \& Friend SH (1998) Drug target validation and identification of secondary drug target effects using DNA microarrays. Nature Medicine 4, 1293-1301.

Marx J (2000) DNA arrays reveal cancer in its many forms. Science 289, 1670-1672.

Meirhaeghe A, Helbecque N, Cottel D \& Amouyel P (1999)
Beta2-adrenoceptor gene polymorphism, body weight and physical activity. Lancet 353, 896.

Nadler ST, Stoehr JP, Schueler KL, Tanimoto G, Yandell BS \& Attie AD (2000) The expression of adipogenic genes is decreased in obesity and diabetes mellitus. Proceedings of the National Academy of Sciences USA 97, 11371-11376.

Nuwaysir EF, Bittner M, Trent J, Barrett JC \& Afshari CA (1999) Microarrays and toxicology: the advent of toxicogenomics. Molecular Carcinogenesis 24, 153-159.

Rininger JA, DiPippo VA \& Gould-Rothberg BE (2000) Differential gene expression technologies for identifying surrogate markers of drug efficacy and toxicity. Drug Discovery Today 5, 560-568.

Roberts M, Geiger W \& German B (2000) The revolution in microanalytic chemistry: a macro-opportunity for clinical nutrition. American Journal of Clinical Nutrition 71, 434-437.

Sallinen SL, Sallinen PK, Haapasalo HK, Helin HJ, Helen PT, Schraml P, Kallioniemi OP \& Kononen J (2000) Identification of differentially expressed genes in human gliomas by DNA microarray and tissue chip techniques. Cancer Research 60, 6617-6622.

Schena M, Shalon D, Davis RW \& Brown PO (1995) Quantitative monitoring of gene expression patterns with a complementary DNA microarray. Science 270, 467-470.

Schena M, Shalon D, Heller R, Chai A, Brown PO \& Davis RW (1996) Parallel human genome analysis: microarray-based expression monitoring of 1000 genes. Proceedings of the National Academy of Sciences USA 93, 10614-10619.

Schuler GD, Boguski MS, Stewart EA, Stein LD, Gyapay G, Rice K, White RE, Rodriguez-Tome P, Aggarwal A, Bajorek E, Bentolila S \& Birren BB et al. (1996) A gene map of the human genome. Science 274, 540-546.

Soukas A, Cohen P, Socci ND \& Friedman JM (2000) Leptinspecific patterns of gene expression in white adipose tissue. Genes and Development 14, 963-980.

Takahashi Y, Nagata T, Asai S, Shintaku K, Egichi T, Ishii Y, Fujii M \& Ishikawa K (2000) Detection of aberrations of 17p and p53 gene in gastrointestinal cancers by dual (two-colour) fluorescence in situ hybridization and GeneChip p53 assay. Cancer Genetics and Cytogenetics 121, 38-43.

Trayhurn P (1998) Molecular biology and nutrition: the quest for integration. British Journal of Nutrition 80, 305-306.

Yang GP, Ross DT, Kuang WW, Brown PO \& Weigel RJ (1999) Combining SSH and cDNA microarrays for rapid identification of differentially expressed genes. Nucleic Acids Research 26, 1517-1523.

Ye P, Lin L, York DA \& Bray GA (2000) cDNA microarray analysis of white adipose tissue of mice after treatment with the B3-agonist CL-316,243. Obesity Research 8, Suppl. 1, 126S. 